\title{
Estimating the Profit Cost Functions, Economic and Technical Efficiencies of Corn Production in Babylon Province in Iraq
}

\author{
Osamah K. Al-Mansi, Zahra H. Mahmood, Nada K. Abbas \\ Department of Agricultural Economics, College of Agriculture, University of Baghdad ,Baghdad, Iraq \\ Email address: \\ usamakadhim@yahoo.com (O. Al-Mansi)
}

\section{To cite this article:}

Osamah K. Al-Mansi, Zahra H. Mahmood, Nada K. Abbas. Estimating the Profit Cost Functions, Economic and Technical Efficiencies of Corn Production in Babylon Province in Iraq. International Journal of Applied Agricultural Sciences. Vol. 1, No. 3, 2015, pp. 66-73.

doi: $10.11648 /$ j.ijaas.20150103.14

\begin{abstract}
The study aimed to estimate the profit and cost functions as well as the economic, price and cost efficiencies of local and hybrid varieties of corn. A random sample of 80 corn farms in Babylon province were selected during the agricultural season 2013. From efficiency scales of profit functions, it was shown that the production size had the greatest impact on the profit of both local and hybrid seeds compared with the other price variables and average production costs. According to the cost functions, the optimal cost-minimizing production sizes were 40.7 ton and 47.77 ton for local and hybrid seeds respectively; while the technical efficiency, economic efficiency, price efficiency and cost efficiency for these seeds were respectively $20.996 \%$ and $49.88 \% ; 20.996 \%$ and $49.88 \% ; 22.34 \%$ and 38.74 ; and 0.49 and 0.59 . From these results it can be concluded that employed economic resources in the production process were not optimally exploited which resulted in a reduction in technical efficiencies for both varieties of seeds. The study recommended to follow production policy aiming to increase the economic efficiency and achieve the optimal usage of available resources.
\end{abstract}

Keywords: Profit Function, Cost Function, Technical Efficiency, Economic Efficiency, Cost Efficiency

\section{Introduction}

Corn is considered one of the most important strategic crops. It ranks fourth after wheat, barley and rice. That is because of the multiuse of corn as human and animal foods beside the role of corn in industries likes oil industry (Younes and Al-Shammaa, 1987). The demand for corn is a derivative demand, and what is produced locally from this crop does not meet the local demand. Many reasons stand for this disequilibrium between production and demand, among which are the high production cost and low yield of acre unit.

This study is based on a hypothesis that corn farmers in Babylon province are achieving profit that enables them to expand their production of corn. Accordingly, the study aimed to estimate profit and total production functions, calculate the production size which maximizes profit and minimizes costs and measure the technical, economic, price and cost efficiency for local and hybrid seed varieties.

Many studies have shed light on the cost function and scale economic of corn. A study by Farhan (2001) revealed high production cost and low yield/acre for this crop in Wasit province which led to decline in farmers' net income both at unit area and farm levels. Montruzzaman and Kaim (2009) in Bangladesh listed the most important determinants facing corn farmers which were low capital and increased price of fertilizers. In Nigeria, Ogundari et al. (2006) reported an average efficiency of production cost of 1.161 which implies that the farmer affords $16 \%$ above marginal cost. The study also revealed the predominance of scale econometric among corn farmers since ES was greater than one. Sadiq et al. (2013) used descriptive analysis to analyze the data of small farms in Nigeria. The study showed 2.5 production efficiency which indicates that the income covers the total cost. In South Africa, Sihlongonyane (2014) reported $64.7 \%$ technical efficiency of corn production, while the allocative efficiency was $99.52 \%$.

\section{Materials and Methods}

Cross-sectional data were obtained through a random sample involved 80 corn farmers in Babylon province during the agricultural season 2013. A well-prepared questionnaire was used for data collection, and statistical package for social science (SPSS) software was used for data analysis. 


\subsection{Descriptive Analysis of Production Costs}

1. Total Variable Cost (TVC)

These included all mechanical processes, production requirements, marketing cost, waged-labor, and maintenance and transportation costs (Table 1). The cost of production requirements has captured the bulk of TVC with $49.88 \%$ and $57.66 \%$ contribution for local and hybrid seeds respectively.

Table 1. Relative importance of items of variable costs for corn crop.

\begin{tabular}{lllll}
\hline \multirow{2}{*}{ Variable cost items } & Hybrid seeds class & \multicolumn{2}{l}{ Local seeds class } \\
\cline { 2 - 5 } & \% Relative importance & Value(thousand dinars) & \% Relative importance & Value(thousand dinars) \\
\hline Production requirements & 57.66 & 92403.3 & 49.88 & 38404 \\
Mechanical costs & 17.78 & 28494.18 & 25.26 & 19445 \\
Marketing costs & 5.079 & 8138.13 & 10.21 & 7861 \\
Labour & 11.2 & 17929.89 & 1.05 & 810 \\
Fuel & 5.36 & 8594.85 & 9.06 & 6978 \\
Maintenance water pump & 2.89 & 4634.85 & 4.35 & 3350 \\
Production transfer requirements & 0.031 & 50 & 0.19 & 145 \\
Total variable costs & 100 & 160245.2 & 100 & 76993 \\
\hline
\end{tabular}

Source: calculated based on the questionnaire form.

\section{2. $\quad$ Fixed Cost (FC)}

Fixed cost involved family labor cost and land rent (Table

2). It can be noticed the low FC of production due to low wage per acre (4.8 thousand dinars) which is the main contributor for FC for both local and hybrid seeds.

Table 2. Relative importance of fixed costsitemsofcorn crop.

\begin{tabular}{lllll}
\hline \multirow{2}{*}{ Fixed cost items } & Hybrid seeds class & & Local seeds class & \\
\cline { 2 - 5 } & \%Relative importance & Value(thousand dinars) & \% Relative importance & Value(thousand dinars) \\
\hline Domestic labour cost & 94.84 & 7415 & 98.45 & 6915 \\
Farm rent & 5.16 & 403.8 & 1.55 & 109 \\
Total fixed cost & 100 & 7818.8 & 100 & 7024 \\
\hline
\end{tabular}

Source: calculated based on the questionnaire form.

3. Total Costs (TC):

Table 3 shows the relative importance of TVC and FC in maize production. Variable costs represented $91.64 \%$ and
$95.35 \%$ for local and hybrid seeds respectively. On the other hand, FC represented only $8.36 \%$ and $4.65 \%$ of these costs respectively.

Table 3. Relative importance of fixed and variable costs from total costs of corn crop planting season 2013 sample study.

\begin{tabular}{lllll}
\hline \multirow{2}{*}{ Total costs items } & Hybrid seeds class & \multicolumn{3}{l}{ Local seeds class } \\
\cline { 2 - 5 } & Value(thousand dinars) & \% Relative importance & Value(thousand dinars) & \% Relative importance \\
\hline Variable cost & 160245.2 & 95.35 & 76993 & 91.64 \\
Fixed cost & 7818.8 & 4.65 & 7024 & 8.36 \\
Total cost & 168064 & 100 & 84017 & 100 \\
\hline
\end{tabular}

Source: calculated based on the questionnaire form.

\section{Results and Discussion}

Ordinary least square (OLS) method was used to estimate the functions of coefficients of short term profit and costs for local and hybrid seeds. Estimation model of profit function was based on the economic theory which states that the profit (net return) equals total return (TR) minus TC (Debertin, 1986). Thus, the profit function can be derived as follows:

$$
\begin{gathered}
\pi=T R-T V C-T F C \\
T R=P_{Q} * Q, T C=P_{X} \cdot X-T F C \\
\pi=\sum P_{Q} \cdot Q-\sum P_{X} \cdot X-T F C
\end{gathered}
$$

Where: $\pi:$ Profit or net return.

$P_{Q}:$ Product price.

$Q$ : Product size.

$X$ : quality of variable resources.

$P_{X}:$ price of variable resources.

$T F C$ : total fixed costs.

From equation 2 , the profit function can be derived as follows:

$$
\pi=\left(P_{Q}, C, Q\right)
$$

Accordingly, the profit function model can specified as follows:

$$
\pi=b_{o}+b_{1} P_{Q}-b_{2} C+b_{3} Q+U_{I}
$$

Where: 
$\pi$. profit or net return

$P_{Q}:$ sale price per ton $(1000 \mathrm{ID})$

$C$ : average production cost (1000 ID/ton)

$Q:$ product size of maize (ton)

$b_{O}:$ intercept

$b_{i}$ : regression coefficients

$U_{I}$ : error term that absorbs the impact of the other relative variables in the model, and which cannot be quantitatively measured.

\subsection{First: Estimation of Profit Function for Local Seeds}

$\pi=-9107.261+21.104 P_{Q}-2.975 C+285.365 Q$

$$
\mathrm{T} \quad(-3.112)^{*}(3.243)^{*}(-3.965)^{*}(34.340)^{* *}
$$

D. $W=2.142 \quad R^{2}=0.978 \quad R^{-2}=0.976$

$R=0.989 \quad F=511.126$

Economic, Statistical and Econometric Analysis of Profit Function

The profit function of for local seed production revealed that signs of all variables were in accordance with the economic theory. Coefficients of product price and production size took the positive sign with profit which indicates a positive relationship between profit and production size with product size. This implies an increase in product price by 1000 ID (with other factors are fixed) results in 21.104 thousand dinars increase in profit; whereas, one ton increase in production (with other factors are fixed) leads to increase in profit by 285.365 thousand dinars. On the other hand, the coefficient of average production cost took the negative sign with the profit, which indicates a reverse relationship between profit and average production costs. This implies that an increase of 1000 ID in production cost (with other factors are fixed) results in 2.976 thousand dinars decrease in profit. It is obvious from coefficients of Scale variables that the amount of output has a great influence on the profit rise (Qamar et al., 2006).

Statistical analysis proved that all variables were significant at 0.01 , and $F$ test proved the significant of the function as whole at the same level. Furthermore, determination coefficient value was 0.978 which means $97.8 \%$ of the changes in the profit backs to independent variables, while only $2.2 \%$ of these changes are attributed to other factors were not included in the model.

In order to clarify the efficiency of estimators, econometric tests were performed for the model. Results of Durbin-Watson test proved the absence of the autocorrelation from model. The test value was 2.142 which is greater than du (1.658) and smaller than 4-du (2.342). Moreover, Klein test, which is based on simple correlation coefficient matrix, prove the passing of the model the multi collinearity problem among the independent variables (Table 4). From the table, it can be concluded that correlation coefficient of the model is greater than simple correlation coefficient for any two independent variables, which indicates the absence of multicollinearity from the model (Gujarati, 2004).
Table 4. Correlation matrix between the independent variables included in the model class for local seed.

\begin{tabular}{llll}
\hline Correlations & \multicolumn{1}{c}{$\boldsymbol{A} \boldsymbol{P} \boldsymbol{C}$} & $\boldsymbol{Q}$ \\
\hline py & & -.099 & .088 \\
Pearson Correlation & 1 & .547 & .596 \\
Sig. (2-tailed) & 39 & 39 & 39 \\
N & & & \\
ATC & -.099 & & $-.377^{*}$ \\
Pearson Correlation & .547 & 1 & .018 \\
Sig. (2-tailed) & 39 & 39 & 39 \\
N & & & \\
Q & .088 & $-.377^{*}$ & 1 \\
Pearson Correlation & .596 & .018 & \\
Sig. (2-tailed) & 39 & 39 & 39 \\
N & & & \\
\hline
\end{tabular}

*Correlation is significant at the 0.05 level (2-tailed).

Depending on the result of Park test, there was no heteroscedasticity problem in the model as in the following equations:

$$
\begin{gathered}
\operatorname{Ln}\left(e i^{2}\right)=a+b(\operatorname{Ln} Q) \\
\operatorname{Ln}\left(e i^{2}\right)=11.100+0.476 \operatorname{Ln} Q \\
t \quad(12.048) \quad(1.538) \\
F=2.366 \\
\operatorname{Ln}\left(e i^{2}\right)=a+b(\operatorname{LnC}) \\
\operatorname{Ln}\left(e i^{2}\right)=17.467-0.802 \operatorname{LnC} \\
t \quad(2.791) \quad(-0.710) \\
F=0.503 \\
\operatorname{Ln}\left(e i^{2}\right)=a+b\left(\operatorname{Ln} P_{Q}\right) \\
\operatorname{Ln}\left(e i^{2}\right)=21.711-1.2091 \operatorname{Ln} P_{Q} \\
t \quad(0.378) \\
F=0.016
\end{gathered}
$$

\subsection{Second: Estimation of Cost Function for Local Seeds}

Multiple models were used for estimation of TC function using three forms of this function (linear, quadratic and cubic). The cubic form was found to be the most appropriate for its harmony with statistical, economic and econometric tests. Thus, according to economic theory, the function of the TC in the short term is:

$$
\begin{array}{r}
\mathrm{TC}=354.811+256.910 \mathrm{Q}-7.106 \mathrm{Q}^{2}+0.076 \mathrm{Q}^{3} \ldots \ldots 4 \\
(\mathrm{t}) \quad(1.156) \quad(3.909)^{* *}(-2.067)^{*}(2.140)^{*} \\
\mathrm{R}^{2}=0.879 \quad \mathrm{~F}=(85.065)^{* *} \quad \mathrm{D} . \mathrm{W}=2.069
\end{array}
$$

\subsubsection{Statistical Analysis}

According to t-test, the estimated coefficients were significant at $5 \%$ and $1 \%$, and the determination coefficient value was 0.879 . This implies that the total yield explains about $87.9 \%$ of changes in the production costs of maize; 
while the other $13.1 \%$ of these changes is attributed to other variables (such as education, experience, age and family size) which were not included in the model.

\subsubsection{Econometric Analysis}

Econometric tests were performed to evaluate the efficiency of estimators. The results indicate the absence of autocorrelation between the residuals according to the value of Durbin-Watson test (2.069) which was greater than du (1.658) and smaller than 4-du (2.342). Besides, the model was proved to have no heteroscedasticity based on Park test (Johnston, 1984).

$$
\begin{gathered}
\operatorname{Ln}\left(e i^{2}\right)=a+b(\operatorname{Ln} Q) \\
\operatorname{Ln}\left(e i^{2}\right)=11.567+0.087 \operatorname{Ln} Q \\
t(12.048) \quad(-0.190)
\end{gathered}
$$

\subsubsection{Economic Analysis}

1. Optimal Cost-Minimizing Production Size.

This production size can be obtained by finding the minimum limit of average of ATC and making this limit equal to zero (17):

$$
A T C=\frac{\partial S R A T C}{\partial Q}=-354.811 Q^{-2}-7.106+0.152 Q
$$

Multiply equation 5 by $Q^{2}$ results that:

$$
-354.811-7.106 Q^{2}+0.152 Q^{3}
$$

Equation 4 can be solved by trial and error, or by Newton approach for solving nonlinear equations (3). This approach requires assuming initial value to find current value. This calculation was repeated until the two values (initial and current) are equal or too closed to achieved the required accuracy i.e. the past value is almost equal to its current counterpart (Zidane and Al-Khater, 2013). The maize yield was then estimated at lowest point of ATC (optimal production average) to be about 47.77 ton. This average is greater than that of actual production which was 10.03.

2. Output bulks for profit:can get production profit through bulks equal marginal cost with price of output (18) and 440 000/tonnes.

$$
\begin{gathered}
256.910-14.212 Q+0.228 Q^{2}=440 \\
-183.09-14.212 Q+0.228 Q^{2}=0
\end{gathered}
$$

Equation 6 can be solved by constitution approach.

$$
Q=\frac{-b \pm \sqrt{b^{2}-4 a c}}{2 a}
$$

According to economic analysis, the production size which maximizes the profit was found to be 73.29 ton which was greater than the optimal production (47.77 ton).

The Minimum Price Acceptable for Farmers to Supply their Product of Maize.

This could be calculated by obtaining the first differentiation of the function of average variable costs and making it equal to zero (17).

$$
\begin{gathered}
S R A V C=256.910-7.106 Q+0.076 Q^{2} \\
\frac{\partial S R A V C}{\partial Q}=-7.106+0.152 Q=0 \\
Q=46.75
\end{gathered}
$$

Thus, the production size at the lowest point of average variable costs was estimated to be about 46.75 ton. By substitution of this value in equation 7 , the minimum value for average variable cost was obtained which was 90.810 thousand dinars that represents the minimum price acceptable by the producers.

\subsubsection{Economic Indices for Actual, Optimal and Profit- Maximizing Levels for Local Seeds}

The study involved the calculation of some economic indices such as net income for three production levels (actual, optimal and profit maximizing) depending on profit equation (19). These levels were respectively found to be 10.03, 47.77 and 73.93 , keeping in mind that 440 thousand dinars /ton is the price of maize.

$$
\begin{gathered}
\pi=T R-T C \\
\pi=440 * Q-\left(354.811+256.910 Q-7.106 Q^{2}\right. \\
\left.+0.076 Q^{3}\right)
\end{gathered}
$$

Substitution of these levels in equation 8 gives the estimated net income to these levels where 2119.77, 16322.35 and 21314.15 thousand dinars respectively (table 5). The greatest net return was achieved at the profit-maximizing production level. However, the optimal production level which minimizes the cost has an advantage that it produces one ton with minimum costs compared with the other levels. These costs were 98.31 /ton, 149.18 thousand dinars/ton and 228.66 thousand dinars/ ton for optimal, profit-maximizing and actual production respectively.

From table 5, it can be noted that the greatest index (341.69 thousand dinars/ton) was for average net return which was achieved at the optimal production level; while the least index was for at actual production level (211.34 thousand dinars/ton). The highest level of profit efficiency (8.92) was achieved at optimal production level. Regarding Dinar return index, it was found that every expended 1000 Dinars on optimal production achieved 3.48 relative increases. The index of achieved profit from total income was in its greatest value at optimal production level followed by profit-maximizing product level and finally the actual production level. That means the total income which is obtained from optimal production level achieved 0.78 profit compared to actual and profit-maximizing production levels (0.48 and 0.66 respectively (Mbah, 2012). From this analysis it can be concluded that optimal production level is the best one. 
Table 5. economic indicators of local seed varieties.

\begin{tabular}{llll}
\hline Index & $\begin{array}{l}\text { Profit max. } \\
\text { product } \\
\text { (thousand } \\
\text { dinars) }\end{array}$ & $\begin{array}{l}\text { Optimal } \\
\text { Production } \\
\text { size (ton) }\end{array}$ & $\begin{array}{l}\text { Actual } \\
\text { product } \\
\text { (ton) }\end{array}$ \\
\hline $\begin{array}{l}\text { Product size (tons) } \\
\text { Total revenue } \\
\text { (thousand dinars) }\end{array}$ & 73.29 & 47.77 & 10.03 \\
$\begin{array}{l}\text { Total costs } \\
\text { (thousand dinars) }\end{array}$ & 32247.6 & 21018 & 4413.2 \\
$\begin{array}{l}\text { Net earnings } \\
\text { (thousand dinars) }\end{array}$ & 10933.45 & 4696.45 & 2293.43 \\
$\begin{array}{l}\text { The average net yield } \\
\text { (thousand dinars / ton) }\end{array}$ & 21314.15 & 16322.35 & 2119.77 \\
$\begin{array}{l}\text { Average total costs } \\
\text { (thousand dinars / ton) }\end{array}$ & 149.18 & 98.31 & 211.34 \\
$\begin{array}{l}\text { Return dinar } \\
\text { Profitability efficiency } \\
\text { Profitability of the total } \\
\text { revenue }\end{array}$ & 1.95 & 4.41 .69 & 228.66 \\
\hline
\end{tabular}

Source: calculated based on the estimated costs and the profit function.

\subsection{Third: Estimation of Profit Function for Hybrid Seeds}

$\Pi=-42688.456+107.665 P_{y}-13.612 C+128.233 Q(11)$

$$
\begin{gathered}
t(-1.689)(1.998)^{*} \quad(-3.928)^{* *} \quad(6.602)^{* *} \\
D . W=1.814 \quad R^{2}=0.701 \quad R^{-2}=0.671 \\
R=0.838 \quad F=22.713
\end{gathered}
$$

$*$ Significant level 0.05

$* *$ Significant level 0.01

\subsubsection{Economic, Statistical and Econometric Analysis of Profit Function}

Similar to that of local seeds, the profit function of production for hybrid seed revealed that signs of all variables were in accordance with the economic theory. Coefficients of product price and production size took the positive sign with profit which indicates a positive relationship between profit and production size with product price. This implies an increase in product price by 1000 ID (with other factors are fixed) results in 107.665 thousand dinars increase in profit; whereas, one ton increase in production (with other factors are fixed) leads to increase in profit by 128.233 thousand dinars. On the other hand, the coefficient of average production cost took the negative sign with the profit, which indicates a reverse relationship between profit and average production costs. This implies that an increase of 1000 ID in production cost (with other factors are fixed) results in 13.612thousand dinars decrease in profit. It is obvious from coefficients of Scale variables that the amount of output has a great influence on the profit rise (Qamar et al., 2006).

Statistical analysis proved that all variables were significant at 0.05 and 0.01 , and $F$ test proved the significant of the function as whole at the same levels. Furthermore, determination coefficient value was 0.701 which means $70.1 \%$ of changes in the profit is explained by independent variables, while only $29.9 \%$ of these changes are attributed to other factors not included in the model.

Econometric tests were performed for the model to evaluate the efficiency of the estimators. Results of Durbin-Watson test proved the absence of the autocorrelation from model. The test value was 1.814 which is greater than du (1.659) and smaller than 4-du (2.341). Moreover, Klein test proved the passing of the model the multi collinearity problem among the independent variables (Table 6). From the table, it can be concluded that correlation coefficient of the model is greater than simple correlation coefficient for any two independent variables, which indicates the absence of multi collinearity problem from the model (Gujarati, 2004).

Table 6. Matrix of correlation between independent variables within the template of a class of hybrid seeds:

\begin{tabular}{llll}
\hline Correlations & \multicolumn{1}{c}{$\boldsymbol{P}_{\boldsymbol{y}}$} & \multicolumn{1}{c}{$\boldsymbol{A T C}$} & \multicolumn{1}{c}{$\boldsymbol{Q}$} \\
\hline \multicolumn{1}{c}{$P_{\boldsymbol{y}}$} & & 0.060 & 0.193 \\
Pearson Correlation & 1 & 0.739 & 0.282 \\
Sig. (2-tailed) & 41 & 41 & 41 \\
N & & & \\
\multicolumn{1}{c}{ ATC } & 0.060 & & -0.004 \\
Pearson Correlation & 0.739 & 1 & 0.982 \\
Sig. (2-tailed) & 41 & 41 & 41 \\
N & & & \\
Q & 0.193 & -0.004 & \\
Pearson Correlation & 0.282 & 0.982 & 1 \\
Sig. (2-tailed) & 41 & 41 & 41 \\
N & & & \\
\hline
\end{tabular}

Depending on the result of Park test, there was no heteroscedasticity problem in the model as in the following equations (Johnston, 1984):

$$
\begin{gathered}
\operatorname{Ln}\left(e i^{2}\right)=a+b(\operatorname{Ln} Q) \\
\operatorname{Ln}\left(e i^{2}\right)=10.521+0.897 \operatorname{Ln} Q \\
t(5.319)^{* *}(1.257) \\
F=1.580 \\
\operatorname{Ln}\left(e i^{2}\right)=a+b(\operatorname{LnC}) \\
\operatorname{Ln}\left(e i^{2}\right)=9.171-0.983 \operatorname{Ln} C \\
t(1.661)(-0.972) \\
F=0.944 \\
\operatorname{Ln}\left(e i^{2}\right)=a+b\left(\operatorname{Ln} P_{Q}\right) \\
\operatorname{Ln}\left(e i^{2}\right)=-21.711+0.5947 \operatorname{Ln} P_{Q} \\
t(-0.177)(0.196) \\
F=0.038
\end{gathered}
$$

\subsection{Fourth: Estimation of Cost function for Hybrid Seeds}

$$
\begin{gathered}
T C=318.327+255.577 Q-4.845 Q^{2}+0.062 Q^{3}(12) \\
t(0.0403)(2.542)^{*}(-2.033)^{*}(3.880)^{* *} \\
R^{2}=0.959 \quad F=226.755 \quad \text { D. } W=1.871
\end{gathered}
$$




\subsubsection{Statistical Analysis}

T-test results revealed the significant of estimated coefficients at 0.05 and 0.01 . The value of determination coefficient was 0.959 which means the changes in the total production are explained about $95.5 \%$ of changes in the production costs of maize. Other variables not included in the study (like education, experience, age and family size) contribute in $4.1 \%$ of these changes.

\subsubsection{Econometric Analysis}

Econometric tests were performed to evaluate the efficiency of estimators. The results indicate the absence of autocorrelation between the residuals according to the value of Durbin-Watson test (1.871) which was greater than du (1.659) and smaller than 4-du (2.341). Besides, the model was proved to have no heteroscedasticity based on Park test (Johnston, 1984).

$$
\begin{gathered}
\operatorname{Ln}\left(e i^{2}\right)=a+b(\operatorname{Ln} Q) \\
\operatorname{Ln}\left(e i^{2}\right)=9.702+0.892 \operatorname{Ln} Q \\
t(5.654)^{* *}(1.441) \\
F=2.077
\end{gathered}
$$

\subsubsection{Economic Analysis}

1. Optimal Cost-Minimizing Production Size

This production size can be obtained by finding the minimum limit of ATC and making this limit equal to zero (Henderson and Quandt, 1980):

$$
\frac{\partial S R A T C}{\partial Q}-318.327 Q^{-2}-4.845+0.124 Q
$$

Multiplying equation 13 by $\mathrm{Q}^{2}$ results in:

$$
-318.327-4.845 Q^{2}+0.124 Q^{3}
$$

Equation 14 can be solved by trial and error, or by Newton approach for solving nonlinear equations (3). This approach requires assuming initial value to find current value. This calculation was repeated until the two values (initial and current) are equal or too closed to achieved the required accuracy i.e. the past value is almost equal to its current counterpart (Zidane and Al-Khater, 2013). The maize yield was then estimated at lowest point of average TC (optimal production average) to be about 40.7 ton. This average is

$$
\begin{gathered}
\pi=T R-T C \\
\pi=440 * Q-\left(318.327+255.577 Q-4.845 Q^{2}+0.062 Q^{3}\right)
\end{gathered}
$$

Substitution of these levels in equation 9 gives the estimated net income to these levels where 4840.38, 10970.4 and 15076.97 thousand dinars, respectively (table 7). The greatest net return was achieved at the profit-maximizing production level. However, the optimal production level which minimizes the cost has an advantage that it produces one ton with minimum costs compared with the other levels. These costs were 170.46thousand dinars/ton, 225.33thousand dinars/ ton and 201.56thousand dinars/ ton for optimal, greater than that of actual production which was 20.3.

2. Profit-Maximizing Production Size

The production level which maximizes the profit can be obtained by equaling the marginal cost with the production price (Penson, 1980) which was $440000 \mathrm{ID} /$ ton.

$$
\begin{gathered}
255.577-9.69 Q+0.186 Q^{2}=440 \\
-184.423-9.69 Q+0.186 Q^{2}=0
\end{gathered}
$$

Equation 16 can be solved by constitution approach.

$$
Q=\frac{-b \pm \sqrt{b^{2}-4 a c}}{2 a}
$$

According to economic analysis, the production size which maximizes the profit was found to be 66.91 ton which was greater than the optimal production (40.7 ton).

3. The Minimum Price Acceptable for Farmers to Supply their Product of Maize

This could be calculated by obtaining the first differentiation of the function of average variable costs and making it equal to zero (Henderson and Quandt, 1980).

$$
\begin{gathered}
S R A V C=255.577-4.845 Q+0.062 Q^{2} \\
\frac{\partial S R A V C}{\partial Q}=-4.845+0.124 Q=0 \\
Q=39.07
\end{gathered}
$$

Thus, the product size at the lowest point of average variable costs was estimated to be about 39.07 ton. By substitution of this value in equation 17 , the minimum value for average variable cost was obtained which was 90.810thousand dinars that represents the minimum price acceptable by the producers.

\subsection{Economic Indices for Actual, Optimal and Profit- Maximizing Levels for Hybrid Seeds}

Economic indices such as net income for three production levels (actual, optimal and profit maximizing) depending on profit equation were used. The above levels were respectively found to be 20.3, 40.7 and 66.91, keeping in mind that 440thousand dinars /ton is the price of maize. profit-maximizing and actual production respectively.

From table 7 , it can be noted that the greatest index (269.54thousand dinars /ton) was for average net return which was achieved at the optimal production level; while the least index was for at actual production level (225.33thousand dinars/ton). The highest level of profit efficiency (1.58) was achieved at optimal production level. Regarding Dinar return index, it was found that every expended one Dinar on optimal production achieved 2.58Dinar increases. The index of 
achieved profit from total income was in its greatest value at optimal production level followed by profit-maximizing production level and finally the actual production level. That means the total income which is obtained from optimal production level achieved 0.61 profit compared to actual and profit-maximizing production levels $(0.54$ and 0.51 respectively) (Mbah, 2012). From this analysis it can be concluded that optimal production level is the best one.

Table 7. Economic indicators of class hybrid seed.

\begin{tabular}{|c|c|c|c|}
\hline Index & $\begin{array}{l}\text { Profit max. } \\
\text { product } \\
\text { (thousand } \\
\text { dinars) }\end{array}$ & $\begin{array}{l}\text { Optimal } \\
\text { production size } \\
\text { (ton) }\end{array}$ & $\begin{array}{l}\text { The actual } \\
\text { product } \\
\text { (ton) }\end{array}$ \\
\hline Product size (tons) & 66.91 & 40.7 & 20.3 \\
\hline $\begin{array}{l}\text { Total revenue } \\
\text { (thousand dinars) }\end{array}$ & 29440.4 & 17908 & 8932 \\
\hline $\begin{array}{l}\text { Total costs } \\
\text { (thousand dinars) }\end{array}$ & 14363.43 & 6937.60 & 4091.62 \\
\hline $\begin{array}{l}\text { Net earnings } \\
\text { (thousand dinars) }\end{array}$ & 15076.97 & 10970.4 & 4840.38 \\
\hline $\begin{array}{l}\text { The average net } \\
\text { yield } \\
\text { (thousand dinars / } \\
\text { ton) }\end{array}$ & 225.33 & 269.54 & 238.4 \\
\hline $\begin{array}{l}\text { Average total costs } \\
\text { (thousand dinars / } \\
\text { ton) }\end{array}$ & 214.67 & 170.46 & 201.56 \\
\hline Return dinar & 2.05 & 2.58 & 2.18 \\
\hline $\begin{array}{l}\text { Profitability } \\
\text { efficiency }\end{array}$ & 1.05 & 1.58 & 1.18 \\
\hline $\begin{array}{l}\text { Profitability of the } \\
\text { total revenue }\end{array}$ & 0.51 & 0.61 & 0.54 \\
\hline
\end{tabular}

Source:-calculated based on the estimated costs and the profit function.

\subsection{Technical Efficiency (TE) of Local and Hybrid Seeds.}

Technical efficiency refers to the production of maximum output using certain amount of resourced, or achievement of the same output with the minimum amount of resources. Technical efficiency can be estimated as follows:

technical efficiency $=($ actual output $\div$ output optimization $)$ $* 100$

The most efficient level of production was achieved when the average yield reached the maximum point, and this represents TE. Table 8 shows that TE of hybrid seeds is higher than that of local seeds, and the farmers of both seeds were able to increase their TE through optimal using of resources.

\subsection{Economic and Price Efficiency of Local and Hybrid Seeds:}

Economic efficiency (EE) refers to the achievement of maximum income (profit) with certain costs, or achievement of the same income with minimum cost (Susan, 2011). EE is divided into two components: technical and price efficiency, and can be estimated as follows:

$$
\text { economicefficiency }=\frac{\text { optimalaveragecost }}{\text { actualaveragecost }} * 100
$$

$$
\begin{gathered}
\text { optimalcost }=\frac{\text { actualcost }}{\text { optimizedoutput }} \\
\text { actualaveragecost }=\frac{\text { actualcost }}{\text { actualoutput }}
\end{gathered}
$$

optimalcost $=$ optimalaveragecost $*$ optimizedoutput

Price efficiency (PE) is the selection of lower cost resources and can be defined as the production of goods and services through the optimal usage of resources regarding their costs (Al-Dabbagh, 2008). PE can be estimated as follows:

$$
\text { priceefficiency }=\frac{\text { economicprice }}{\text { actualprice }}
$$

Economic price (EP) is a price which equals the total average costs at their lower limit and the product at which achieves the ordinary profit. EP can be estimated from total average costs (Al-Dabbagh, 2011).

From table 8, it is clear that EE and PE of hybrid seeds are higher than that of local seeds.

Table 8. The economic efficiency and price of two local seed and hybrid.

\begin{tabular}{lll}
\hline Paragraphs & $\begin{array}{l}\text { Hybrid } \\
\text { seedsclass }\end{array}$ & $\begin{array}{l}\text { Local } \\
\text { seedsclass }\end{array}$ \\
\hline Actual output(tons) & 20.3 & 10.03 \\
Optimum output(tons) & 40.7 & 47.77 \\
Technical efficiency \% & 49.88 & 20.996 \\
The actual costs(thousand dinars) & 168064 & 84017 \\
$\begin{array}{l}\text { Optimal averagecosts(thousand } \\
\text { dinars) }\end{array}$ & 4129.34 & 1758.78 \\
The actual average costs(thousand & 8279.01 & 8376.57 \\
dinars) & 168064.14 & 84016.92 \\
Optimal costs(thousand dinars) & 49.88 & 20.996 \\
Economic efficiency\% & 170.46 & 98.31 \\
Economic Price (thousand dinars) & 440 & 440 \\
The actual price(thousand dinars) & 38.74 & 22.34 \\
Price\% efficiency & & 2293.43 \\
Total costs when the actual production & 4091.62 & \\
volume & & 4696.45 \\
The total cost of production at the & 6937.60 & 0.49 \\
optimal size & 0.59 & \\
Costefficiency &
\end{tabular}

Source:-calculated based on the estimated cost function.

\subsection{Cost Efficiency of Local and Hybrid Seeds.}

Cost efficiency can be obtained by dividing TC at actual production level by $\mathrm{TC}$ at optimal production level, and calculated according to the following formula:

$$
C E=\left(C i^{b i} \div C i^{m i n}\right)
$$

Where:

$C E:$ cost efficiency

$C i^{b i}$ : TC at optimal production level

$C i^{\text {min }}$ : TC at actual production level

Cost efficiency may take more or less than the correct one. It is achieved when it takes the correct one value (Paudel and Matduoka, 2009). Cost efficiency for local and hybrid seeds were less than the correct one which implies that resources 
were not optimally exploited.

From the aforementioned results, it can be concluded that production size has the greatest impact on profit function of local and hybrid seeds compared with other price variables and production cost average. According to TE and CE, the economic resources used for production were not optimally exploited; a case which led to a decrease in production efficiency and an increase in the production cost of local and hybrid seeds. Calculation of prices which achieved the optimal production (98.31thousand dinars /ton and 170.46thousand dinars /ton for local and hybrid seeds respectively) and comparing them with the priced determined by the state to purchase maize (440thousand dinars/ton) revealed the determined price satisfied the farmers. Through this price, they can achieve profits that encourage them to continue and expand their production.

According to the economic indices, hybrid seeds farmers are better than local seed farmers regarding actual production size. Therefore, there was a tendency for farmers to use hybrid variety despite its high price.

The study recommends to follow a production policy aims to increase economic efficiency of local and hybrid seeds and to achieve the optimal usage of available resources.

\section{References}

[1] Al-Dabbagh, H. H.(2008). Economics ofAgricultural Marketing, first edition, Baghdad-Iraq.

[2] Debertin, D. (1986). Agricultural Production Economics MacMillan Publishing Company, New York. P:41.

[3] Farhan, M. O. (2001). Economic analysis of the cost functions maize crop in Wasit Province for 1999, Journal of agricultural science, vol. 32, no. 3. Pp. 196-191.

[4] Gujarati, D. (2004). Basic Econometrics McGraw-Hill Book Co. New York,p:387.

[5] Henderson, H. and Quandt, G. (1980). Microeconomic Theory. A Mathematical Approach, Third Edition, McGraw-Hill, Inc, Landon,p:140.
[6] Johnston,M. (1984). Econometric Methods . McGaw - Hill Book, Inc., $3^{\text {rd }}$ Edition, pp:160-172.

[7] Mbah, S. O. (2012). Profitability of honey production enterprise in Umuahia agricultural zone of Abiastata , Nigeria.15(3) pp: 1268- 1274.

[8] Monlruzzaman, M.S. and Karim, Q.M. (2009). Agro economic analysis of maize production in Bangladash : A farm Level study . Bangladesh J. Agri. Res. 34 (1) pp:2-15.

[9] Ogundari, S. O. and Ajibefun, I. A. (2006). Economic of scale and cost efficiency in small scale maize production : Empirical evidence from Nigeria . J. Soc. Sci., 13 (2):pp:131-136.

[10] Paudel, A. and Matsuoka, A. (2009). Cost efficiency estimates of maize production in Nepal : a case study of the Chitwan district. Agric. Econ. -Czech, 55(3) pp:139-148.

[11] Penson, J. B. (1980).Introduction to agricultural economics, prentice Hill. New Jersey pp:124-129.

[12] Qamar, W.; Khan, N.P.; Ahmad, M. F. and Idress, M. (2006). Economics of Tabacco production in District Swabi , NWFP.J. Agric. Biol. Sci., 1(3) pp: 30-35.

[13] Sadiq, M.S. and Mohmmed, A. B. (2013). Profitability and production efficiency of small scale maize production in Niger stata, Nigeria. Iosr. J. Appl. physical 3 (4):pp: 19-23.

[14] Sihlongonyane, M . B and Masuka. M. B. (2014). Economic efficiency of maize production in Swaziland: the case of hhohho, Manzini and Shiselweni regions. Res.Appl. Economics, 6(3) : pp: 179- 195.

[15] Susan, C.B. (2011). Technical and allocative efficiency of samallholder maize farmers in Zambia. Institutional Repository, P:23.

[16] Younes, A. H. Al-Shammaa, W. S. (1987). Grain crops. Ministry of higher education and scientific research, the University of Mosul. p. 220-227.

[17] Zalkuwi, J. W. and Dia, R. Z. (2010). Analysis of Economic efficiency of maize productionin Nigeria, Report and Opinion, $2(7): p p: 1-6$.

[18] Zidane, G. and Al-Khater, S. F. (2013). Measuring the efficiency of crop production and marketing peanut field in Diyala province, Diyala agricultural science magazine, 5, (2):163-155. 